\title{
Morphometric analysis of phosphate and chromium interactions in Cyclotella meneghiniana
}

\author{
Diane Lazinsky and Linda Sicko-Goad \\ Center for Great Lakes and Aquatic Sciences, The University of Michigan, Ann Arbor, MI, U.S.A.
}

(Received 29 July 1989; revision received 5 October 1989; accepted 10 October 1989)

\begin{abstract}
Quantitative electron microscopy was used to evaluate interactive effects of chromium additions and phosphate nutrient status on the diatom Cyclotella meneghiniana. Cells of differing phosphate status were exposed to hexavalent chromium for 7 days and morphological changes in both phosphate alone and phosphate and chromium treatments were observed. Changes in chloroplast relative volume and number/ volume were observed in all treatments. Changes in mitochondrial and vacuolar volume and an increase in presumed autophagic activity were apparent in all chromium treatments. An increase in polyphosphate was also found in most chromium treated cells. These morphological modifications are discussed in relation to changes observed with exposure to other heavy metals.
\end{abstract}

Key words: C. meneghiniana; Chromium; Quantitative electron microscopy; Morphology; Phosphate

\section{INTRODUCTION}

Chromium is known to exert adverse and, in many cases; toxic effects on algal cells. Reduction in growth rate (Wium-Anderson 1974; Azeez and Banerjee 1988), depression of chlorophyll, inhibition of cell proliferation (Fasulo et al., 1982; 1983), and reduction in survival rate (Yongue et al., 1979) have been reported as chromium effects on various algae.

It appears that chromium sensitivity may be species dependent and that environmental factors may be important in altering chromium effects. Chromium toxicity to Selenastrum was not effectively changed by variations in $\mathrm{pH}$ (Michnowicz and Weaks 1984), but salinity increases did reduce toxic effects in estuarine diatoms (Frey et al., 1983). Riedel $(1984,1985)$ found that sulphate concentrations affect chromium toxicity and suggested that sulphate and chromium compete for uptake in Thalassiosira pseudonana.

Previously (Sicko-Goad et al., 1986; Sicko-Goad and Lazinsky, 1986), we examined the synergistic effects of nutrients and lead on a diatom and suggested that cells

Correspondence to: L. Sicko-Goad, Center for Great Lakes and Aquatic Sciences, The University of Michigan, 2200 Bonisteel Blvd., Ann Arbor, MI 48109-2099, U.S.A. 
sufficient in nutrients could be less susceptible to toxicity effects of metals. To further investigate nutrient-metal interactions, an experiment was designed to evaluate the effects of chromium on Cyclotella and to determine if these effects are in any way modified by the phosphate status of the cell. The results of this experiment are presented in the following paper.

\section{MATERIALS AND METHODS}

A unialgal culture of Cyclotella meneghiniana (Clone $\mathrm{CYOH}$, provided by Dr. Susan Kilham) was grown in WC medium (Guillard, 1975) at $20^{\circ} \mathrm{C}, 200 \mu \mathrm{Ein} \mathrm{M}^{-2} \cdot \mathrm{s}^{-1}$ of illumination on a light-dark cycle of 16:8. Cells from 7-day cultures were transferred and maintained at either a phosphate sufficient or deficient level. After 7 days, chromium $\left(\mathrm{K}_{2} \mathrm{Cr}_{2} \mathrm{O}_{7}\right)$ at a concentration of $0.2 \mu \mathrm{g}$-at $/ 1$ and phosphate $\left(\mathrm{K}_{2} \mathrm{HPO}_{4}\right)$, as noted below, were added to the cells to yield the following experimental treatments:

Phosphate sufficient $+C r$ : Cells that were maintained continuously in medium containing the standard amount of phosphate in WC medium before chromium addition.

Phosphate deficient $+C r$ : Cells that were maintained in phosphate free medium for 7 days before chromium addition.

Phosphate uptake $+\mathrm{Cr}$ uptake: Cells that were maintained in phosphate free medium for 7 days and then twice the standard amount of phosphate was added at the same time as the chromium addition.

Phosphate uptake $+\mathrm{Cr}$ : Cells that were maintained in phosphate free medium for 7 days and then twice the standard amount of phosphate was added. Chromium was added $3 \mathrm{~h}$ after the phosphate addition.

Cells that were maintained with the above phosphate status with no chromium additions served as experimental controls. These experiments were designed to simulate a 'one-time' exposure and subsequent dilution. Reported concentrations of both phosphate and chromium are nominal and were not measured throughout the experiment. Previous work (Sicko-Goad and Lazinsky, 1986) demonstrated that transfer of polyphosphate rich Cyclotella cells to phosphate deficient medium did not result in significant morphological changes after 7 days, presumably due to a lower phosphate turnover rate.

To monitor the progress of the cells throughout the experiment, a limited number of duplicate samples was taken for carbon and chlorophyll $a$ analyses at 3 and 7 days following chromium additions. Results of these analyses are reported as the mean in Table I. Particulate carbon was analyzed in an HP model 185B CHN Analyzer according to the methods of Davis and Simmons (1979). The procedure for chlorophyll $a$ consisted of extraction with $90 \%$ acetone (Davis and Simmons, 1979) followed by analysis in a Turner 111 fluorometer.

For electron microscopy, aliquots of cell suspensions were withdrawn from all treatments and placed into $50 \mathrm{ml}$ centrifuge tubes after an incubation period of 7 


\section{TABLE I}

Carbon and chlorophyll levels for 3 and 7 day phosphate and chromium treatments.

\begin{tabular}{|c|c|c|c|c|}
\hline \multirow[t]{2}{*}{ Treatments $^{\mathrm{a}}$} & \multicolumn{2}{|c|}{ Carbon (mg/l) } & \multicolumn{2}{|c|}{ Chlorophyll $\left(\mathrm{mg} / \mathrm{m}^{3}\right)$} \\
\hline & $3 \mathrm{D}$ & $7 \mathrm{D}$ & $3 \mathrm{D}$ & $7 \mathrm{D}$ \\
\hline P SUFF & 2.93 & 4.00 & 48.2 & 59.3 \\
\hline $\mathrm{PSUFF}+\mathrm{Cr}$ & 2.54 & 2.79 & 36.6 & 26.9 \\
\hline P DEF & 1.09 & 1.24 & 7.0 & 5.0 \\
\hline $\mathrm{PDEF}+\mathrm{Cr}$ & 1.03 & 1.33 & 7.6 & 6.1 \\
\hline P-UP & 1.42 & 2.26 & 13.1 & 29.7 \\
\hline P-UP + Cr UP & 1.39 & 1.93 & 11.9 & 16.8 \\
\hline $\mathrm{P}-\mathrm{UP}+\mathrm{Cr}$ & 1.33 & 1.62 & 10.5 & 14.4 \\
\hline
\end{tabular}

${ }^{a}$ Treatment code: $\mathrm{P}$ SUFF $=\mathrm{P}$ sufficient $; \mathrm{P}$ SUFF $+\mathrm{Cr}=\mathrm{P}$ sufficient + chromium; $\mathrm{P}$ DEF $=\mathrm{P}$ deficient; $\mathrm{P} D E F+\mathrm{Cr}=\mathrm{P}$ deficient + chromium; P-UP $=\mathrm{P}$ uptake; $\mathrm{P}-\mathrm{UP}+\mathrm{Cr} \mathrm{UP}=\mathrm{P}$ uptake with chromium added simultaneously; $\mathrm{P}-\mathrm{UP}+\mathrm{Cr}=\mathrm{P}$ uptake with chromium added following the period of overplus $(3 \mathrm{~h})$.

days. The samples were fixed in $1 \%$ paraformaldehyde-glutaraldehyde in $0.05 \mathrm{M}$ sodium cacodylate buffer, $\mathrm{pH} 7.2$, for $1 / 2 \mathrm{~h}$ at $4^{\circ} \mathrm{C}$ (Lazinsky and Sicko-Goad, 1979). The samples were pelleted by centrifugation between all solution changes during the fixation and embedding procedure. Samples were post fixed in $1 \%$ osmium tetroxide and sodium cacodylate buffer for $1 \mathrm{~h}$ at $4^{\circ} \mathrm{C}$, dehydrated in a graded ethanol-propylene oxide series, and embedded in Epon (Luft, 1961).

Thin sections were cut with a diamond knife, collected on formvar coated copper grids, and stained with aqueous uranyl acetate (Watson, 1958). Electron micrographs were taken on a JEOL JEM 100B electron microscope operating at $80 \mathrm{kV}$. For quantitative estimates of cellular organelles or functional compartments such as vacuole, random sections were obtained through embedded pellets of the algae. Thirty micrographs were obtained at a standard magnification of $22300 \times$. A transparent $10 \mathrm{~mm}$ square sampling lattice was placed over the pictures for estimates of volume and numerical density using the grid point-counting techniques (Glagoleff, 1933; Chalkley, 1943) with precautions taken for sampling unicells (Sicko-Goad et al., 1977; SickoGoad and Stoermer, 1979; Sicko-Goad, 1982; Sicko-Goad et al., 1986). The pointcounting method is an extension of the Delesse principle which states that the areal density of profiles on 'two-dimensional' sections is an unbiased estimate of the volume density of the corresponding structures within the tissues (Delesse, 1847, cited in Weibel and Bolender, 1973). Thus, by counting points of a sampling grid striking a component, and comparing that quantity with a containing area measured in the same units, an unbiased estimate of the volume fraction of the component in the original tissue can be obtained. Additional information concerning the more theoretical aspects of stereology can be found in one of several excellent reviews on the subject (Loud, 1968; Underwood, 1970; Weibel and Bolender, 1973). 
Morphological changes are reported as quantitative volume $\left(V_{\mathrm{v}}\right)$ or numerical $\left(N_{\mathrm{v}}\right)$ changes in organelles and cellular compartments determined to be of physiological and morphological significance (Sicko-Goad et al., 1977). Those compartments (ribosomes, Golgi, and occasionally small vesiculate structures sometimes observed in diatoms) which are difficult to quantify as separate entities due to either their rare occurrence or extremely small volume on a comparative basis, are listed in Table II as a composite category 'Other'. These estimates were used to calculate the percent change among cells of differing phosphate status and also between the chromium treatments and their respective controls (i.e., the difference between phosphate sufficient and chromium treated phosphate sufficient cells).

Estimates of cell volume were obtained from light microscopic examination of epoxy-embedded cells. Estimates were based on 25 independent measurements and assume a regular geometric shape of a cylinder. No significant changes were observed in average cell size throughout the course of the experiment.

\section{RESULTS}

The results of carbon and chlorophyll $a$ analyses are presented in Table I. Carbon levels increase in all treatments over time. However, all treatments contain less carbon than phosphate sufficient cells, and chromium treated cells, exclusive of those deficient in phosphate, have reduced carbon levels compared to their respective controls. Similarly, chlorophyll values are reduced in the chromium treatments relative

\section{TABLE II}

Morphometric results of phosphate and chromium treatments after 7 days. Values are the mean \pm SE.

\begin{tabular}{|c|c|c|c|c|c|c|c|}
\hline & \multicolumn{7}{|c|}{ Treatments $^{2}$} \\
\hline & P SUFF & $\mathrm{PSUFF}+\mathrm{Cr}$ & P DEF & $\mathrm{PDEF}+\mathrm{Cr}$ & P-UP & $\mathrm{P}-\mathrm{UP}+\mathrm{Cr} \mathrm{UP}$ & $\mathrm{P} \cdot \mathrm{UP}+\mathrm{Cr}$ \\
\hline Chloroplast $V_{\mathrm{v}}$ & $\begin{array}{l}23.0 \\
(1.5)\end{array}$ & $\begin{array}{l}17.0 \\
(1.2)\end{array}$ & $\begin{array}{l}14.1 \\
(1.0)\end{array}$ & $\begin{array}{l}13.5 \\
(0.9)\end{array}$ & $\begin{array}{l}12.6 \\
(1.0)\end{array}$ & $\begin{array}{l}16.1 \\
(1.5)\end{array}$ & $\begin{array}{l}16.4 \\
(1.5)\end{array}$ \\
\hline Chloroplast $N_{\mathrm{v}}$ & $\begin{array}{r}0.22 \\
(0.03)\end{array}$ & $\begin{array}{r}0.10 \\
(0.02)\end{array}$ & $\begin{array}{r}0.16 \\
(0.04)\end{array}$ & $\begin{array}{r}0.15 \\
(0.02)\end{array}$ & $\begin{array}{c}0.12 \\
(0.01)\end{array}$ & $\begin{array}{r}0.10 \\
(0.02)\end{array}$ & $\begin{array}{r}0.13 \\
(0.03)\end{array}$ \\
\hline Mitochondria $V_{\mathrm{v}}$ & $\begin{array}{c}3.4 \\
(0.6)\end{array}$ & $\begin{array}{c}2.7 \\
(0.4)\end{array}$ & $\begin{array}{c}3.5 \\
(0.6)\end{array}$ & $\begin{array}{r}2.4 \\
(0.5)\end{array}$ & $\begin{array}{c}3.1 \\
(0.5)\end{array}$ & $\begin{array}{r}4.0 \\
(0.4)\end{array}$ & $\begin{array}{r}4.0 \\
(0.5)\end{array}$ \\
\hline Mitochondria $N_{v}$ & $\begin{array}{r}0.10 \\
(0.02)\end{array}$ & $\begin{array}{c}0.12 \\
(0.04)\end{array}$ & $\begin{array}{r}0.19 \\
(0.06)\end{array}$ & $\begin{array}{c}0.16 \\
(0.04)\end{array}$ & $\begin{array}{c}0.05 \\
(0.01)\end{array}$ & $\begin{array}{c}0.13 \\
(0.02)\end{array}$ & $\begin{array}{c}0.11 \\
(0.01)\end{array}$ \\
\hline Lipid $V_{v}$ & $\begin{array}{r}6.3 \\
(1.6)\end{array}$ & $\begin{array}{l}11.2 \\
(1.2)\end{array}$ & $\begin{array}{l}29.1 \\
(2.4)\end{array}$ & $\begin{array}{l}33.2 \\
(3.1)\end{array}$ & $\begin{array}{l}11.3 \\
(1.6)\end{array}$ & $\begin{array}{l}11.2 \\
(1.6)\end{array}$ & $\begin{array}{l}11.3 \\
(2.0)\end{array}$ \\
\hline
\end{tabular}


TABLE II (continued).

\begin{tabular}{lccccccc}
\hline Nucleus $V_{\mathrm{v}}$ & 9.5 & 12.7 & 7.4 & 8.9 & 11.7 & 10.7 & 12.2 \\
& $(2.0)$ & $(1.4)$ & $(1.9)$ & $(2.4)$ & $(1.6)$ & $(1.8)$ & $(2.1)$ \\
Other $V_{\mathrm{v}}$ & 16.0 & 15.5 & 10.8 & 8.0 & 14.1 & 20.4 & 20.8 \\
& $(1.1)$ & $(1.0)$ & $(1.1)$ & $(0.9)$ & $(1.0)$ & $(1.5)$ & $(1.2)$ \\
Vacuole $V_{\mathrm{v}}$ & 29.7 & 26.8 & 22.8 & 21.4 & 33.0 & 21.2 & 21.4 \\
& $(2.1)$ & $(1.2)$ & $(2.0)$ & $(2.0)$ & $(1.9)$ & $(1.8)$ & $(1.7)$ \\
Frustule $V_{\mathrm{v}}$ & 11.7 & 10.9 & 11.9 & 11.6 & 13.0 & 11.6 & 11.6 \\
& $(0.7)$ & $(0.7)$ & $(0.8)$ & $(0.5)$ & $(0.7)$ & $(0.6)$ & $(1.1)$ \\
Autophagic-like & 0 & 2.0 & 0.2 & 0.7 & 0.2 & 2.9 & 1.0 \\
vacuole $V_{\mathrm{v}}$ & 0 & $(0.4)$ & $(0.1)$ & $(0.2)$ & $(0.1)$ & $(0.5)$ & $(0.2)$ \\
& & & & & & & \\
Polyphosphate $V_{\mathrm{v}}$ & 0.4 & 1.3 & 0.1 & 0.1 & 1.1 & 2.0 & 1.3 \\
& $(0.1)$ & $(0.2)$ & $(0.1)$ & $(0.1)$ & $(0.5)$ & $(0.4)$ & $(0.2)$ \\
\hline
\end{tabular}

"Treatment Code, see Table I.

to the controls. Phosphate-sufficient cells treated with chromium exhibit a decrease from 3 to 7 days, while chromium-treated uptake cells show an increase in chlorophyll from 3 to 7 days. Phosphate-deficient cells, both $\mathrm{Cr}$ treated and control, have considerably less chlorophyll than other treatments and there is a decrease over time.

The results of morphometric analysis (Table II) indicate that cells sufficient in phosphate exhibit expected characteristics such as a small amount of polyphosphate and no autophagic vacuole (Fig. 1). In comparison, P-sufficient cells exposed to chromium show a sizeable increase in autophagic vacuole and polyphosphate relative volume $\left(V_{v}\right)$, as well as an increase in lipid relative volume (Fig. 2). Reductions in chloroplast and mitochondrial chloroplast $\left(N_{\mathrm{v}}\right)$ relative volume and number/volume are also apparent in chromium treated P-sufficient cells.

Phosphate-deficient cells have a small relative volume of autophagic vacuole and polyphosphate. In comparison to P-sufficient cells, P-deficient cells exhibit a reduction in chloroplast relative volume and a substantial increase in the relative volume of lipid (Fig. 3). Chromium exposure results in a further increase in lipid $V_{v}$ (Fig. 4). P-deficient cells treated with chromium also appear to show an increase in autophagic activity and an apparent breakdown of membrane integrity which is evident in the chloroplasts.

Phosphate uptake cells show similarities to P-deficient cells in that there are reductions in chloroplast relative volume and number/volume and an increase in lipid relative volume. In contrast to P-deficient cells, P-uptake cells are characterized by the presence of polyphosphate bodies with an increase in polyphosphate relative vol- 


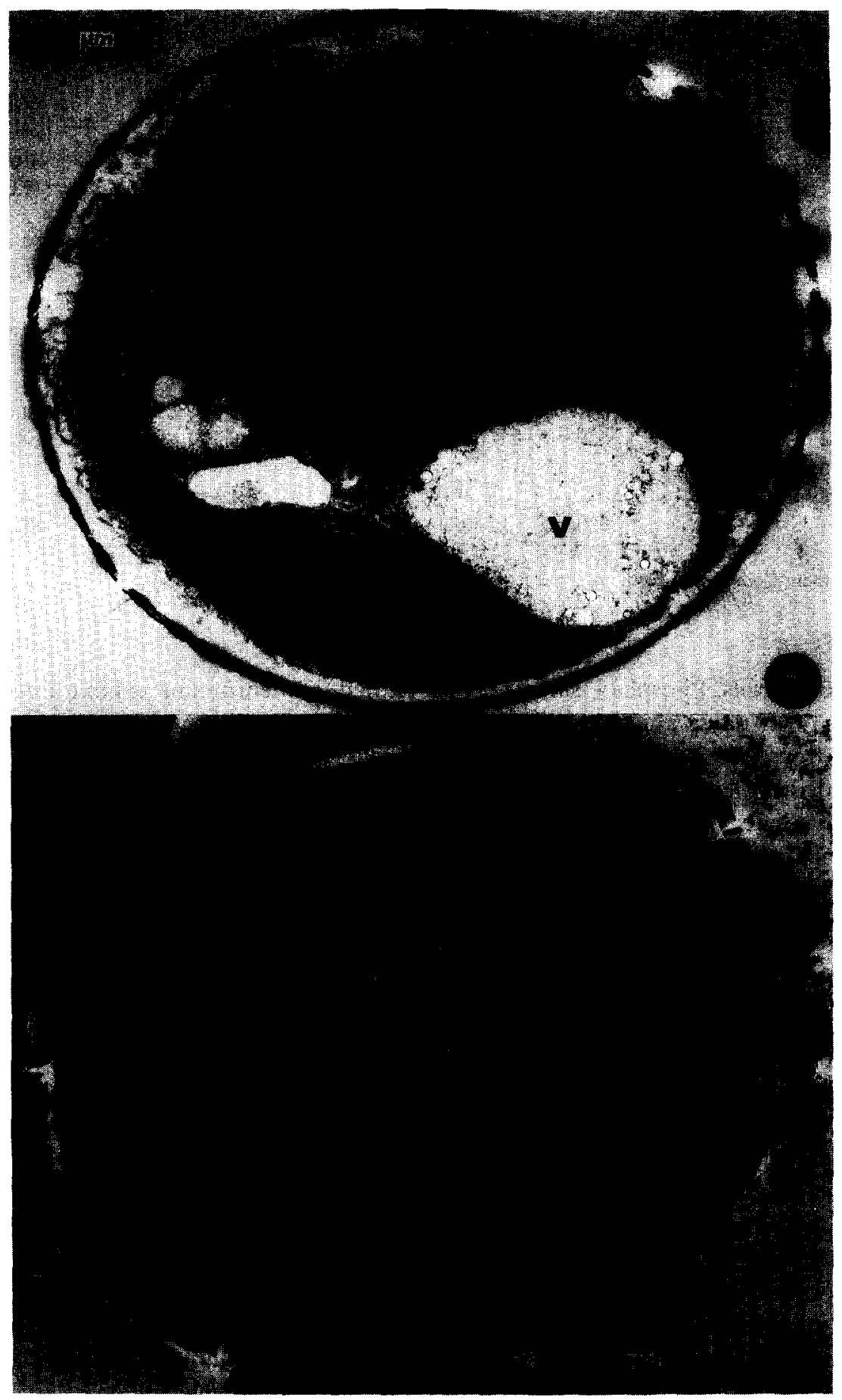

Figs. 1-5. Electron micrographs of Cyclotella meneghiniana. Key to figure legends: autophagic vacuole (AV), chloroplast (C), frustule (F), lipid (L), mitochondria (M), polyphosphate (P), vacuole (V).

Figs. 1 and 2. 1. Phosphate sufficient cell. Chloroplasts, nucleus and vacuole are present. 2. Phosphate sufficient cell treated with $\mathrm{Cr}$ for 7 days. Numerous polyphosphate bodies and a large area of lipid are evident. 


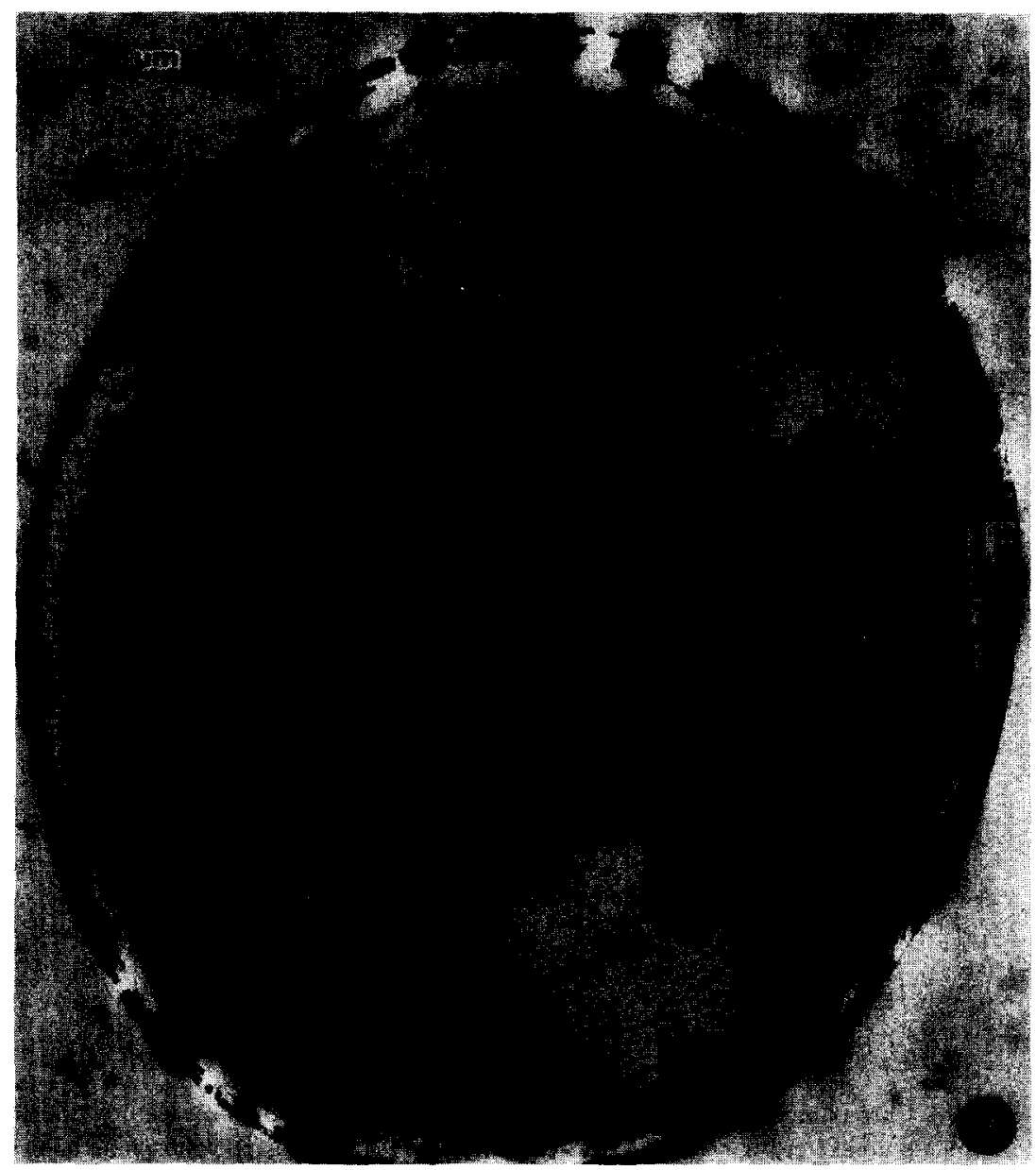

Fig. 3. Phosphate-deficient cell showing nucleus, chloroplasts and lipid.

ume. An increase in polyphosphate volume is also apparent in cells treated with phosphate and chromium simultaneously (chromium coupled uptake) and in cells which received chromium $3 \mathrm{~h}$ after the phosphate addition (Fig. 5). The increase is greater in the chromium coupled uptake treatment. The relative volume of autophagic vacuole also increases in P-uptake cells exposed to $\mathrm{Cr}$ and this too is greater in the chromium coupled uptake. Uptake treatments are very similar in their response to chromium and many of the cellular components are essentially the same. Other changes for uptake chromium treatments include increases in chloroplast and mitochondrial volume. A decrease in vacuole $V_{\mathrm{v}}$ is accompanied by an increase in other $V_{\mathrm{v}}$ as shown in Fig. 6 . Figure 6 also demonstrates a similarity in trends between P-sufficient cells treated with $\mathrm{Cr}$ and $\mathrm{P}$-deficient cells treated with $\mathrm{Cr}$. These treatments also show a similar increase in nuclear relative volume. 


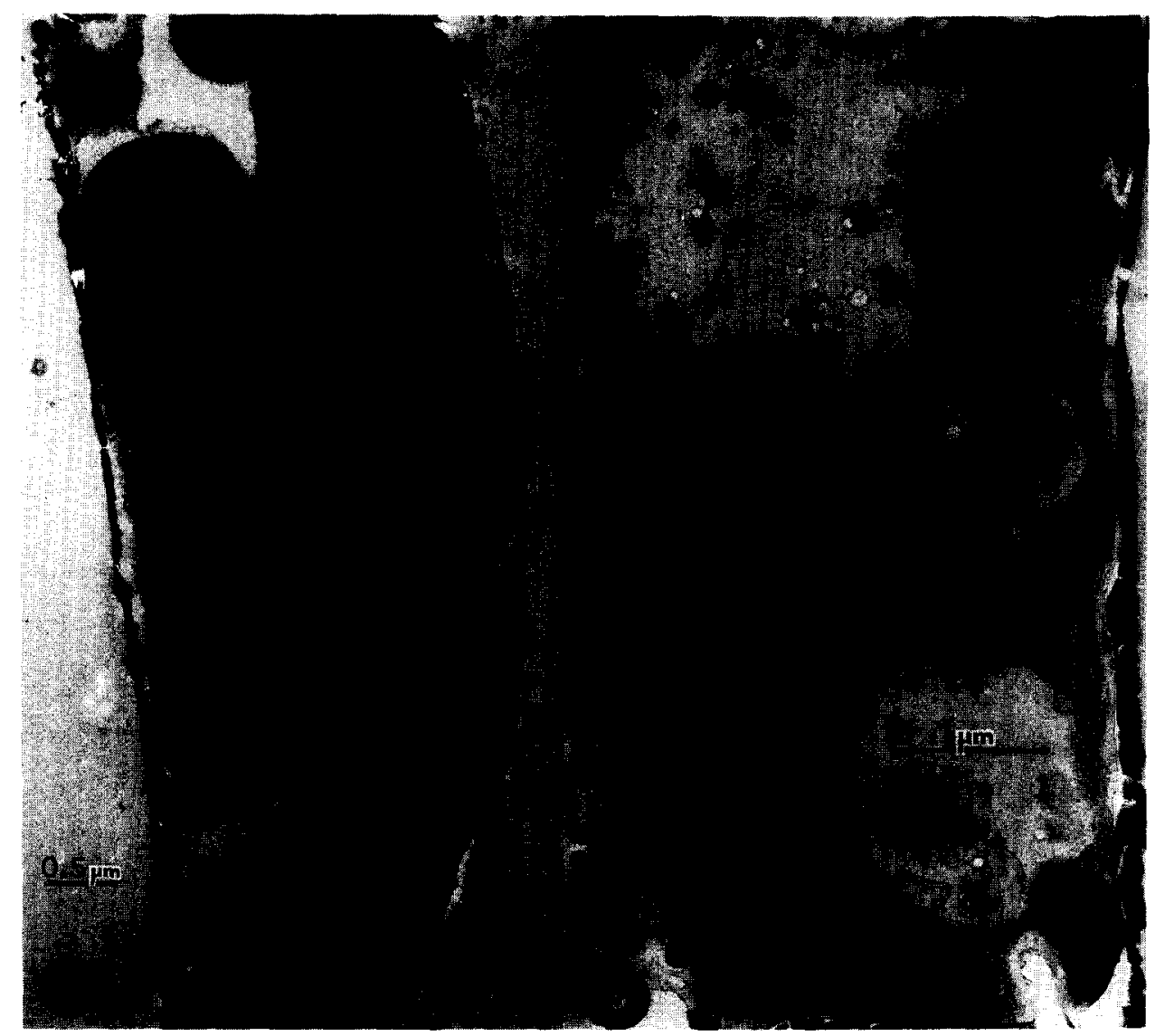

Figs. 4 and 5. 4. Chromium-treated phosphate-deficient cell. Lipid is a prominent feature. 5. Chromiumtreated phosphate uptake cell ( $\mathrm{Cr}$ added $3 \mathrm{~h}$ after $\mathrm{P}$ addition). Numerous polyphosphate bodies can be observed.

\section{DISCUSSION}

The results of carbon and chlorophyll analyses in this study indicate that hexavalent chromium may exert toxic effects on algal cells. A number of studies have compared the toxic effects of chromium on various algae with other metals. Chromium has been found to be less toxic than $\mathrm{Cu}$ (Wium-Anderson, 1974); Cu, Cd, Ni (Azeez and Banerjee, 1988); and $\mathrm{Cu}, \mathrm{Zn}, \mathrm{Ge}, \mathrm{Hg}, \mathrm{Cd}, \mathrm{Pb}$ (Thomas et al., 1980). Hollibaugh et al. (1980) ranked toxicities of ten metals on natural algal populations and Thalassiosira and gave $\mathrm{Cr}$ a low toxicity ranking. However, a study in our laboratory (unpubl. results) run under identical experimental conditions as the current study suggests that $\mathrm{Cr}$ may be more toxic than $\mathrm{Cu}, \mathrm{Zn}$, and $\mathrm{Cd}$. Chromium treatments consistently produced the lowest carbon and chlorophyll values as compared to all 


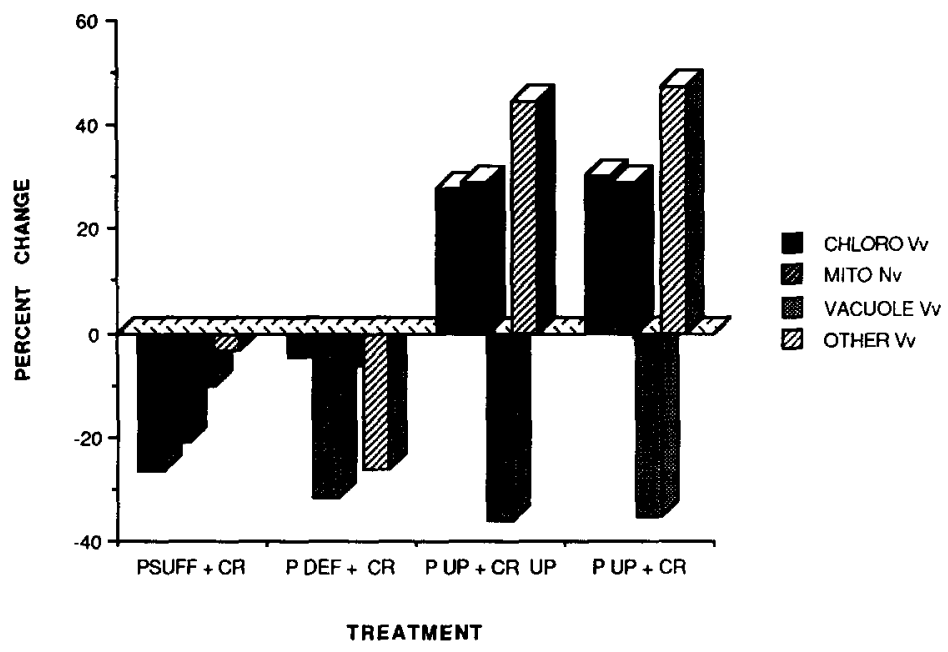

Fig. 6. Percent change in four cellular compartments of $C$. meneghiniana as a result of chromium exposure. Changes reported are relative volume changes $\left(V_{v}\right)$ for other, vacuole and chloroplast. Mitochondrial percent change is the change in number per volume $\left(N_{\mathrm{v}}\right)$. For treatment codes, refer to Table I.

treatments with $\mathrm{Cu}, \mathrm{Zn}$, and $\mathrm{Cd}$ except for cells deficient in phosphate. The reasons for these differences in toxic effects are unclear, but may include several possibilities. Chromium may indeed produce more toxic effects in Cyclotella under our experimental conditions, or the effects of $\mathrm{Cu}, \mathrm{Zn}$, and $\mathrm{Cd}$ may be modified to a greater extent by phosphate status and/or different mechanisms may be involved in chromium toxicity.

Quantitative morphological changes with chromium in this study show similarities to results obtained with other heavy metals. Membrane damage and associated autophagic activity, represented by membranous organelles and residual bodies, have been found with zinc and mercury exposure (Smith, 1983) and lead exposure (Silverberg, 1975; Heumann 1987; Sicko-Goad and Stoermer, 1979; Sicko-Goad and Lazinsky, 1986; Sicko-Goad et al., 1986). Changes in vacuole volume and an increase in autophagic vacuole as a consequence of chromium treatment in this study are in agreement with the above findings. Similarly, ultrastructural studies with bean plants have shown that membrane damage is the primary effect of chromium treatment (Vázquez et al., 1987). Fasulo et al. (1982; 1983) studied the effects of chromium on the ultrastructure of Euglena and found a reduction in chloroplast integrity, enlarged mitochondria, and abnormal vacuolization, which the author suggests may be related to autophagic activity.

Increases in polyphosphate relative volume were observed in chromium treatments, but most notably in cells that were sufficient in phosphate and in $\mathrm{Cr}$ coupled phosphate uptake cells. These observations are in agreement with other studies that have shown that polyphosphate formation may be enhanced by exposure to heavy 
metals (Sicko-Goad and Stoermer, 1979; Lazinsky and Sicko-Goad, 1983; Stoermer et al., 1980). Heavy metals may be sequestered in polyphosphate bodies (Sicko-Goad and Stoermer, 1979; Baxter and Jensen, 1980; Lazinsky and Sicko-Goad, 1983; Jensen et al., 1982a; 1982b; Rachlin et al., 1985; Stoermer et al., 1980) and although chromium accumulation has been studied in blue green (Azeez and Banerjee, 1988) and green algae (Schroll, 1978; Jana, 1988), there are, to our knowledge, no reports of $\mathrm{Cr}$ in algal polyphosphate bodies. However, Kunst and Roomans (1985) have detected $\mathrm{Cr}$ in yeast polyphosphate bodies. Additionally, $\mathrm{Cr}$ has caused precipitates of an unknown nature in bean root cells (Vázquez et al., 1988) and electron dense bodies were observed in aquatic moss grown in water contaminated with $\mathrm{Cr}$ and $\mathrm{Cu}$ (Mouvet, 1984).

Other morphological changes appear to be attributed to either phosphate treatment or phosphate and chromium treatment and, in some cases, are more treatment specific. For example, chloroplasts appear to be affected by both chromium additions and phosphate status. Mitochondria relative volume, on the other hand, appears to be relatively unaffected by phosphate status, but a $>20 \%$ is observed with chromium additions. Our data also demonstrate that the volume of individual mitochondria decreases across all chromium treatments. Apparent increases in relative volume are due to increases in the numbers of mitochondria rather than swelling.

When all treatments are compared to the P-sufficient cells, P-deficient cells treated with $\mathrm{Cr}$ show the greatest number of changes, but some of these changes are a consequence of $\mathrm{P}$ deprivation, and chromium exposure tends to enhance the trend. For example, lipid volume increases from ca. $6 \%$ to $29 \%$ under phosphate deficient conditions. Phosphate deficient cells exposed to chromium have, on average, approximately $33 \%$ of their cell volume occupied by lipid. When comparisons are made among treatments, a similar number of significant changes are observed in P-sufficient cells exposed to $\mathrm{Cr}$ and chromium coupled $\mathrm{P}$-uptake cells relative to controls. However, these changes do not follow along similar lines. In fact, significant morphological changes in the P-sufficient-chromium treatment are interestingly most similar to those found in P-uptake cells (with no $\mathrm{Cr}$ addition). This similarity may be viewed in different ways. Cells sufficient in phosphate may be less affected by chromium and thus resemble $P$ uptake cells. On the other hand, $P$ uptake cells may be still under stress from previous starvation and, therefore, phosphate stress and chromium stress may be characteristically similar. It is possible that chromium interferes with phosphate uptake, but this is unlikely because of the formation of polyphosphate bodies in the chromium treatment. The treatment with the greatest volume of polyphosphate is chromium-coupled $\mathrm{P}$ uptake in which chromium and phosphate were added simultaneously.

Hexavalent chromium is anionic in water and it has been suggested that its toxicological mechanisms may differ from those of cationic metals (Frey et al., 1983; Riedel 1984). Antagonistic relationships between anionic metals and their nutritional analogues have been proposed as probable causes for the toxic action of anionic metals. 
Some examples of such relationships have been reported and include interactions between sulfate and chromium (Riedel, 1985), selenium and sulfate (Wheeler et al., 1982), and selenium and phosphate (Moede et al., 1980).

The results presented here indicate that morphological changes observed with chromium exposure may be somewhat similar to changes with cationic metals. However, the extent of changes with chromium appears to be greater and more varied. Further indications are that, because of the complexities of metal-nutrient interactions, it is difficult to determine whether interactions are synergistic or antagonistic. The evidence reported here suggests a relationship between phosphate nutrient status and chromium may exist, but the extent and exact nature of such a relationship can only be determined with further study.

\section{ACKNOWLEDGEMENT}

This work was supported by Grant R807516 from the Office of Exploratory Research, U.S. Environmental Protection Agency. Contribution No. 520 of the University of Michigan Center for Great Lakes and Aquatic Sciences.

\section{REFERENCES}

Azeez, P.A. and D.K. Banerjee, 1988. Effect of chromium on cyanobacteria and its accummulation. Toxicol. Environ. 16, 229-240.

Baxter, M. and T.E. Jensen, 1980. Uptake of magnesium, strontium, barium, and manganese by Plectonema boryanum (Cyclophyceae) with special reference to polyphosphate bodies. Protoplasma 104, $81-89$.

Chalkley, H.W., 1943. Methods for the quantitative morphologic analysis of tissues. J. Nat. Cancer Inst. 4, 47-53.

Davis, C.O. and M.S. Simmons, 1979. Water chemistry and phytoplankton field and laboratory procedures. Univ. Michigan Great Lakes Div. Spec. Rep. No. 70, Ann Arbor.

Delesse, M.A., 1847. Procédé méchanique pour déterminer la composition des roches. C.R. Acad. Sci. (Paris) 25, 444.

Fasulo, M.P., M. Bassi and A. Donini, 1982. Cytotoxic effects of hexavalent chromium in Euglena gracilis. I. First observations. Protoplasma 110, 39-42.

Fasulo, M.P., M. Bassi and A. Donini, 1983. Cytotoxic effects of hexavalent chromium in Euglena gracilis. II. Physiological and ultrastructural studies. Protoplasma 114, 35-43.

Frey, B.E., G.F. Riedel, A.E. Bass and L.F. Small, 1983. Sensitivity of estuarine phytoplankton to hexavalent chromium. Estuar. Coast Shelf Sci. 17, 181-187.

Glagoleff, A.A., 1933. On the geometrical methods of quantitative mineralogic analysis of rocks. Trans. Inst. Econ. Mineral Metal, Vol. 59, Moscow.

Guillard, R.R.L., 1975. Culture of phytoplankton for feeding marine invertebrates, In: Culture of marine invertebrate animals, edited by W.L. Smith and M.H. Chanley, Plenum, New York, pp. 39-59.

Heumann, H-G., 1987. Effects of heavy metals on growth and ultrastructure of Chara vulgaris. Protoplasma 136, 37-48.

Hollibaugh, J.T., D.L.R. Seibert and W.H. Thomas, 1980. A comparison of the acute toxicities of ten metals to phytoplankton from Saanich Inlet, B.C., Canada. Estuar. Coast Shelf Sci. 10, 93-105.

Jana, S., 1988. Accumulation of $\mathrm{Hg}$ and $\mathrm{Cr}$ by three aquatic species and subsequent changes in several physiological and biochemical plant parameters. Water Air Soil Pollut. 38, 105-109. 
Jensen, T.E., M. Baxter, J.W. Rachlin and V. Jani, 1982a. Uptake of heavy metals by Plectonema boryanum (Cyanophyceae) into cellular compartments, especially polyphosphate bodies: an X-ray energy dispersive study. Environ. Pollut. Ser. A 27, 119-127.

Jensen, T.E., J.W. Rachlin, V. Jani and B. Warkentine, 1982b. An X-ray energy dispersive study of cellular compartmentalization of lead and zinc in Chlorella sacchariophila (Chlorophyta), Navicula incerta and Nitzschia closterium (Bacillariophyta). Environ. Exp. Bot. 22, 319-328.

Kunst, L. and G.M. Roomans, 1985. Intracellular localization of heavy metals in yeast by X-ray microanalysis. Scanning Electron Microsc. 1985; I, 191-199.

Lazinsky, D. and L. Sicko-Goad, 1979. Paraformaldehyde-glutaraldehyde as a routine phytoplankton fixative. Micron 10, 49-50.

Lazinsky, D. and L. Sicko-Goad, 1983. Ultrastructural modification of three blue-green algae following heavy metal exposure. Micron. Micros. Acta 14, 257-258.

Loud, A.C., 1968. A quantitative stereological description of the ultrastructure of normal rat liver parenchymal cells. J. Cell Biol. 37, 27-45.

Luft, J.H., 1961. Improvements of epoxy embedding methods. J. Biophys. Biochem. Cytol. 9, 409-414.

Mitchnowicz, C.J. and T.E. Weaks, 1984. Effects of $\mathrm{pH}$ on toxicity of $\mathrm{As}, \mathrm{Cr}, \mathrm{Cu}, \mathrm{Ni}$ and $\mathrm{Zn}$ to Selenastrum capricornutum Printz. Hydrobiologia 118, 299-305.

Moede, A., R.W. Greene and D.F. Spencer, 1980. Effects of selenium on the growth and phosphorus uptake of Scenesdesmus dimorphus and Anabaena cylindrica. Environ. Exp. Bot. 20, 207-212.

Mouvet, C., 1984. Accumulation of chromium and copper by the aquatic moss Fontinalis antipyretica $\mathrm{L}$ ex Hedw. transplanted in a metal-contaminated river. Env. Tech. Lett. 5, 541-548.

Rachlin, J.W., T.E. Jensen and B.E. Warkentine, 1985. Morphometric analysis of the response of Anabaena flos-aquae and Anabaena variabilis (Cyanophyceae) to selected concentrations of zinc. Arch. Environ. Contam. Toxicol. 14, 395-402.

Riedel, G.F., 1984. Influence of salinity and sulfate on toxicity of chromium (VI) to the estuarine diatom Thalassiosira pseudonana. J. Phycol. 20, 496-500.

Riedel, G.F., 1985. The relationship between chromium (VI) uptake, sulfate uptake, and chromium (VI) toxicity in the estuarine diatom Thalassiosira pseudonana. Aquat. Toxicol. 7, 191-204.

Schroll, H., 1978. Determination of the absorption of $\mathrm{Cr}^{+6}$ and $\mathrm{Cr}^{+3}$ in an algal culture of Chlorella pyrenoidosa using ${ }^{51} \mathrm{Cr}$. Bull. Environ. Contam. Toxicol. 20, 721-724.

Sicko-Goad, L., 1982. A morphometric analysis of algal response to low dose, short-term heavy metal exposure. Protoplasma 110,75-86.

Sicko-Goad, L. and D. Lazinsky, 1986. Quantitative ultrastructural changes associated with lead-coupled luxury phosphate uptake and polyphosphate utilization. Arch. Environ. Contam. Toxicol. 15, 617-627.

Sicko-Goad, L. and E.F. Stoermer, 1979. A morphometric study of lead and copper effects on Diatoma tenue var. elongatum (Bacillariophyta). J. Phycol. 15, 316-321.

Sicko-Goad, L., E.F. Stoermer and B.G. Ladewski, 1977. A morphometric method for correcting phytoplankton cell volume estimates. Protoplasma 93, 147-163.

Sicko-Goad, L., B.G. Ladewski and D. Lazinsky, 1986. Synergistic effects of nutrients and lead on the quantitative ultrastructure of Cyclotella. Arch. Environ. Contam. Toxicol. 15, 291-300.

Silverberg, B.A., 1975. Ultrastructural localization of lead in Stigeoclonium tenue (Chlorophyceae, Ulotrichales) as demonstrated by cytochemical and X-ray microanalysis. Phycologia 14, 265-274.

Smith, M.A., 1983. The effect of heavy metals on the cytoplasmic fine structure of Skeletonema costatum (Bacillariophyta). Protoplasma 116, 14-23.

Stoermer, E.F., L. Sicko-Goad and D. Lazinsky, 1980. Synergistic effects of phosphorus and heavy metal loadings on Great Lakes phytoplankton. USEPA 600/9-80-034, U.S. Environmental Protection Agency, Duluth, MN, pp. 171-186.

Thomas, W.H., J.T. Hollibaugh and D.L.R. Seibert, 1980. Effects of heavy metals on the morphology of some marine phytoplankton. Phycologia 19, 202-209.

Underwood, E.E., 1970. Quantitative stereology. Addison-Wesley, Reading, Mass., 274 pp. 
Vázquez, M.D., C. Porschenrieder and J. Barceló, 1987. Chronium VI induced structural and ultrastructural changes in bush bean plants (Phaseolus vulgaris L.). Ann. Bot. 59, 427-438.

Watson, M.L., 1958. Staining tissue sections for electron microscopy with heavy metals. J. Biophys. Biochem. Cytol. 4, 475-478.

Weibel, R.R. and R.B. Bolender, 1973. Stereological techniques for electron microscopic morphometry. In: Principles and techniques of electron microscopy. Biological applications, Vol. 3, edited by M.A. Hayat, Van Nostrand Reinhold, New York, pp. 239-296.

Wheeler, A.E., R.A. Zingaro and K. Irgolic, 1982. The effect of selenate, selenite, and sulfate on the growth of six unicellular marine algae. J. Exp. Mar. Biol. Ecol. 57, 181-194.

Wium-Andersen, S., 1974. The effect of chromium on the photosynthesis and growth of diatoms and green algae. Physiol. Plant 32, 308-310.

Yongue, Jr., W.H., B.L. Berrent and J. Cairns, Jr., 1979. Survival of Euglena gracilis exposed to sublethal temperature and hexavalent chromium. J. Protozool. 26, 122-125. 